\title{
The Effect of Learning Model STAD (Student Team Achievement Division) Assisted by Media Quizizz on Motivation and Learning Outcomes in Class XI Indonesian History Subjects at SMA Trimurti Surabaya
}

\author{
Iwan Yulianto ${ }^{1, a^{*}}$, Warsono ${ }^{1, b}$, Nasution ${ }^{1, c}$ \& Dwi Bagus Rendy A.P ${ }^{1, d}$ \\ 1 Postgraduate Social Studies Education, Surabaya State University, Surabaya, 602311, Indonesia \\ a soebakree@gamil.com; d dwi.bagus@trunojoyo.ac.id \\ *Corresponding Author : soebakree@gamil.com [ Phone: 08563112624]
}

\begin{abstract}
Social studies education as a science combines a number of selected concepts from branches of social science and other sciences. Students are less motivated in learning history. This condition arises because the variation in historical learning is still lacking because teachers only use traditional methods that place the teacher as the center of information. The Quizizz media-assisted STAD model has the potential to overcome the problems of motivation and student learning outcomes at Trimurti High School. The study was conducted to determine the effect of the STAD (Student Team Achivement Division) learning model assisted by the Quizizz media on motivation and learning outcomes in Indonesian History subjects class XI at Trimurti High School Surabaya. This research is an experimental study using pretest-posttest control group design. The treatment in the experimental class was the application of the STAD (Student Team Achievement Division) learning model assisted by the Quizizz media and the direct learning model (MPL) applied to the control class also assisted by the Quizizz media. T test shows the value of sig $0.03<0.05$, so there are differences in the value of the motivation of students in the control class with the experimental class. $T$ test shows the value of sig $0.002<0.05$, so there are differences in the value of student learning outcomes in the control class with the experimental class.
\end{abstract}

Keywords: STAD; Quizizz; Learning Motivation;bLearning Outcomes;

\section{Introduction}

Social studies education as a science combines a number of selected concepts from the branches of social and other sciences. In the 2013 curriculum, the term IPS is still used at the junior high school level as a combination of social subjects consisting of Geography/Population, History, and Economics/Cooperatives. The organization of the IPS program is generally carried out in an integrated and linked manner (correlated / broadfields). (Wiyono, 2011). Historical Science is one component of the social sciences. The main objective of social science education is to introduce children to their past and present, as well as their geographic and social environment. Effective social science learning programs in schools will make students interested in the way of life of society and its functions through various socio-economic and political institutions. However, it is very unfortunate that history as one of the subjects of the social science family, currently experiences various problems, especially a decrease in student motivation to study it seriously and optimally (Widja, 1989).

Learning motivation is an important factor needed by students. Harahap (2013) states that the intensity (strength) of learning is largely determined by motivation (Harahap, 2013), so that in learning, the stronger one's motivation in learning, the more optimal the activity and learning outcomes. Internal and external factors are the main aspects that support the change in motivation of students, for example, a large responsibility for the task (Cole, 2004). In order to optimize learning, a teacher plays a very important role. Another teacher's role is not only required to have the ability in theoretical experience but also to have practical abilities. Students are less motivated in learning history. This condition arises because the variation in learning history is still lacking because teachers only use traditional methods that place the teacher as the center of information. This practice results in students being less motivated in learning. The purpose of 
learning history is that students have the skills to think and act creatively, productively, critically, independently, collaboratively and communicatively (Permendikbud, 2016). Problem solving, thinking critically, creatively, systematically and logically are skills that students must have in facing the times. Less than optimal learning outcomes can be seen from the results of the Joint Daily Assessment (PHB) in the even semester for Indonesian History subjects in class XI SMA Trimurti Surabaya, science and social studies programs which are still low with 77 school KKM (Minimum Completion Criteria) scores for class level. XI. The value of PHB history in Indonesia shows that $19.3 \%$ of the total number of students in class XI have reached the KKM, while $80.6 \%$ of other students have not reached the KKM.

One of the efforts that are expected to be able to answer these problems is the STAD (Student Team Achievement Division) type of cooperative learning model. STAD is a learning model that emphasizes the Student Team Learning process, namely learning based on the principle that students must be able to be responsible when learning together for their own learning or the learning of their group members (Slavin, 2015). The basic concept of student team learning includes individual responsibility, group rewards, and the opportunity for equal success (Huda, 2013). Vygotsky emphasized that there is a direct relationship between the cognitive domain and socio-culture. The use of the STAD model can also be collaborated with the use of IT-based learning media.

In fact, there are many IT-based media that have been developed today. However, the authors are interested in using one of the IT-based learning media, namely Quizizz. Quizizz is a web tool for creating interactive quiz games that can be used as a learning medium that is proven to be able to attract students' interest (Zhao, 2019). This media also allows it to be accessed from anywhere via student cell phones. STAD model assisted by Quizizz media has the potential to solve problems regarding motivation and learning outcomes of students at Trimurti High School. This research was originally to be carried out in schools, but due to the corona virus pandemic that has hit Indonesia recently, it has an impact on the emergence of a policy that students must learn from home. This has an impact on changing the learning process from classbased to distance learning (online). Therefore, the author intends to carry out a study entitled The effect of the STAD (Student Team Achivement Division) learning model assisted by Quizizz media on motivation and learning outcomes in Indonesian History subjects class XI at SMA Trimurti Surabaya.

\section{Methods}

This study is an experimental study using a pretest-posttest control group design. The treatment in the experimental class was the application of the STAD (Student Team Achievement Division) learning model assisted by the Quizizz media and the direct learning model (MPL) which was applied to the control class as well as the Quizizz media. The target population (grand population) in this study were students at SMA Trimurti Surabaya, while the parent population in this study were students of class XI SMA Trimurti Surabaya as many as 147 students. The samples selected in this study were class XI MIPA 1 (30 students) as the experimental class and class XI MIPA-2 (30 students) as the control class.

Instruments in data collection in this study were test sheets and motivation questionnaire sheets. Researchers can see the learning outcomes and motivation of students in this study. There are pretest and posttest for learning outcomes and student motivation. Then the results are tested using SPSS to analyze the results of the data that has been obtained. Tests conducted in the form of normality test, homogeneity test, and $t$ test (independent and dependent).

\section{Results and Discussion}

The learning motivation of students is measured using a learning motivation questionnaire sheet. Questionnaire sheets were given to students in the experimental class and control class before and after receiving treatment. The pretest of learning motivation questionnaire aims to determine the initial motivation of students before receiving treatment. Question statements in the questionnaire totaled 32 items. . The learning motivation of students in the experimental class shows that there are 5 students $(17 \%)$ who have strong learning motivation in achieving achievement in learning, 14 students (47\%) have moderate learning motivation, and 11 students $(37 \%)$ has a weak learning motivation category in achieving learning outcomes. In the control class, it shows that there are 3 students $(10 \%)$ who have strong learning motivation in achieving achievement, 13 students (43\%) have medium category learning motivation, and 14 students $(47 \%)$ have weak learning motivation.

The data shows that the pretest learning motivation in the experimental class is more in the moderate category, while the control class is more in the weak learning motivation category. The pretest results of the further learning motivation questionnaire can be seen through the following histogram. 


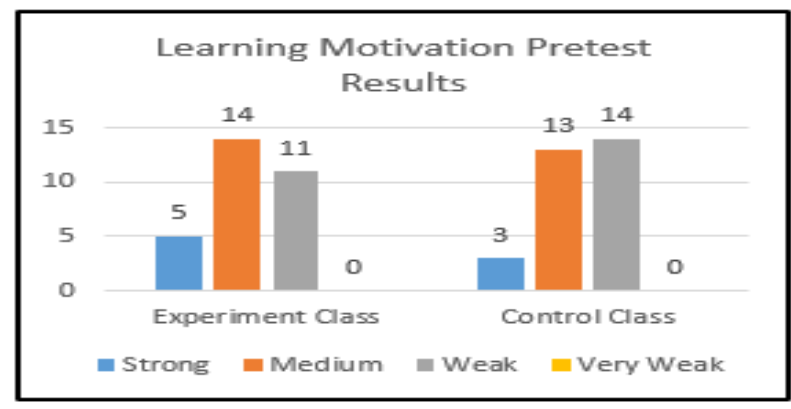

Graph 1. Histogram of Motivation Pretest

Figure 1. Histogram of Motivation Pretest

Changes in students' learning motivation on the post-test results showed that the experimental class was more dominant. The strong category of learning motivation increased to 14 students $(47 \%)$, and the weak learning motivation decreased to 2 students (2\%). In the control class, learning motivation with a strong category also experienced a better change, namely 6 students $(20 \%)$ and motivation with a weak category decreased to 8 students $(27 \%)$. The two treatments, both the experimental class and the control class, can change the learning motivation of students, but in the experimental class, the changes have a bigger impact when compared to the control class. The post-test value data for the experimental class and control class can be seen through the following histogram.

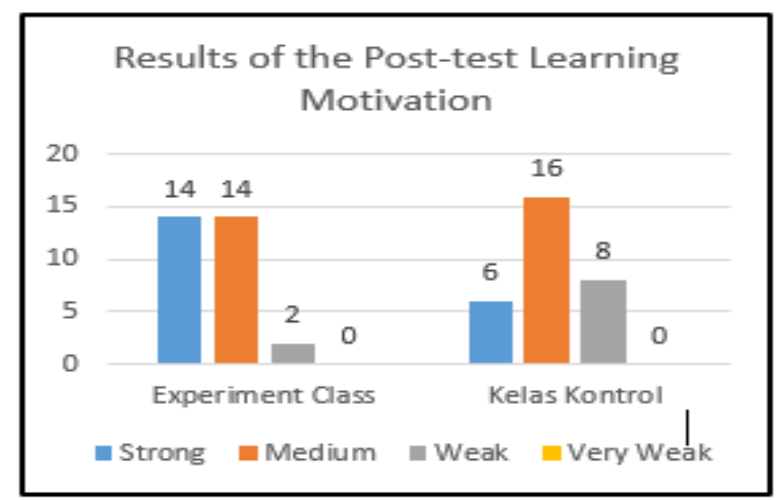

Graph 2. Histogram for Postest Motivation

Figure 2. Histogram of Motivation

The results of the pretest students' knowledge on strategy material and the form of the Indonesian nation's struggle in an effort to defend independence from the threat of the Allies and the Netherlands, the sub-chapter between war and diplomacy in the experimental class were 10 students $(33.33 \%)$ with good categories, 17 students $(56,67 \%)$ in the sufficient category, and 3 students $(10 \%)$ in the poor category. In the control class it can be seen that a number of 8 students $(26.67 \%)$ are in good category, 20 students $(66.67 \%)$ are in the enough category, and 2 students $(6.67 \%)$ are in the poor category. The data shows that the two classes are mostly students with sufficient categories, which means there is not too much difference. The results of the pretest learning outcomes can be seen through the following histogram.

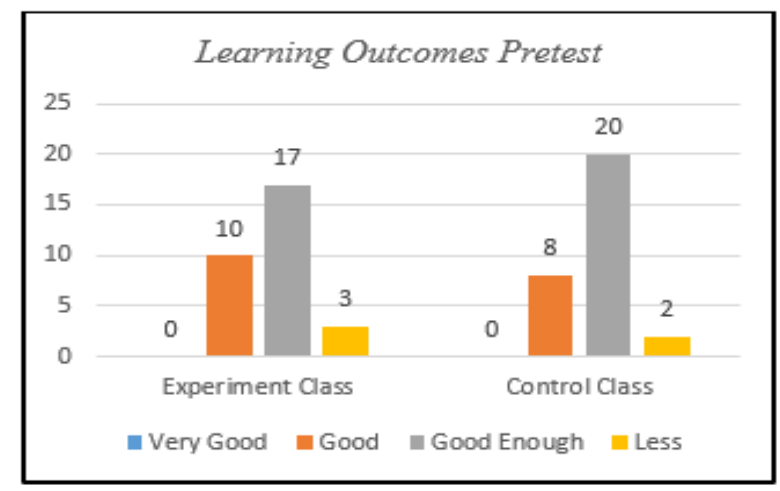

Graph 3. Histogram of Learning Outcomes Pretest

Figur 3. Histogram of Learning Outcomes Pretest 
The posttest results of students' learning outcomes on strategy material and the form of the Indonesian nation's struggle in an effort to defend independence from the threat of the Allies and the Netherlands, subchapter Between War and Diplomacy in the experimental class were 11 students $(36.67 \%)$ in the very good category, 19 students (63.33\%) with good category. In the control class it can be seen that a number of 3 students $(10 \%)$ were in the very good category, 21 students $(70 \%)$ were in the good category, and 6 students $(20 \%)$ were in the Enough category. The difference in the results of the final test or posttest results of student learning can be seen through the following histogram.

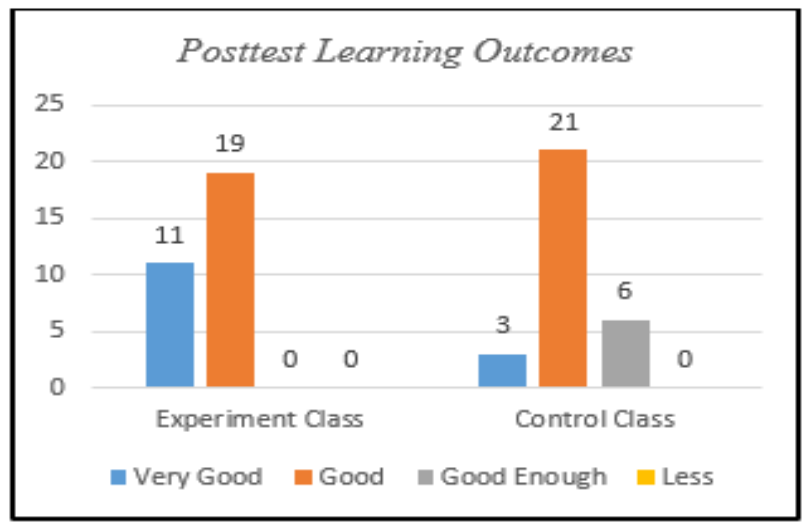

Graph 4. Postest Histograms of Learning Outcomes

Figure 4. Postest Histogram of Learning Outcomes

The normality and homogeneity test of the pretest and posttest data on the learning motivation of students in the Shapiro-Wilk column with the help of SPSS 24 showed numbers above 0.05, both in the experimental class and the control class. Thus it is said that the pretest and posttest data on students' learning motivation are normally distributed and homogeneous for the experimental or control class. Furthermore, the $t$ dependent test was carried out in each experimental class and control class. The dependent $t$ test in the experimental class (sig: 0.01) and control (sig: 0.03) obtained a sig value <0.05, indicating a difference in learning motivation in each class before and after being treated. Then tested the independent test to compare the value of motivation between the experimental class and the control class. The $t$ test shows a sig value of $0.03<0.05$, so there is a difference in the motivation value of students in the control class and the experimental class.

The normality and homogeneity test of the pretest and posttest data on the learning outcomes of students in the Shapiro-Wilk column with the help of SPSS 24 showed numbers above 0.05, both in the experimental class and the control class. Thus it is said that the pretest and posttest data on student learning outcomes are normally distributed and homogeneous for the experimental or control class. Furthermore, the $t$ dependent test was carried out in each experimental class and control class. The dependent $t$ test in the experimental class (sig: 0.00) and control (sig: 0.01) obtained a sig value $<0.05$, indicating a difference in learning outcomes in each class before and after treatment. Then tested the independent test to compare the value of learning outcomes between the experimental class and the control class. The $t$ test shows the sig value of $0.002<0.05$, so there is a difference in the value of student learning outcomes in the control class and the experimental class.

STAD learning, students are required to be able to show the results of learning together with their group friends through a written test or quiz using Quizizz media. The value of the quiz shows the development of student learning outcomes, especially on individual knowledge. When students share knowledge with their friends, this knowledge will become personal knowledge known as private speech. Individual development consistently shows the effectiveness of the learning model. According to Vygotsky, a person's cognitive development which is based on language development is divided into four, namely preintellectual speech, naïve psychology, egocentric speech, and inner speech (Baharudin, 2015).

\section{Conclusion}

STAD learning model assisted by Quizizz media has a significant effect on the learning motivation of students. This influence is shown by changes in the learning motivation of students. Good motivation will create a good learning atmosphere in the classroom. STAD learning model with quizzes assisted by Quizizz media and group awards, is able to make students more enthusiastic about learning without any distinction, so that students are motivated to achieve. STAD learning model assisted by Quizizz media has a significant effect on student learning outcomes in the Indonesian History subject. This is indicated by the increase in 
learning outcomes in students. The existence of good learning outcomes can occur because of good motivation too. The synergy between the STAD learning model which is assisted by the Quizizz media is proven to be able to increase learning motivation so that it contributes to improving student learning outcomes.

\section{References}

Allen, IE, Seamen, J. \& Garret, R. (2007). Blending in: The extent and promise of blended education in the United States, USA: The Sloan Consortium.

Afandi, Muhamad. (2013). Model dan Metode Pembelajaran Di Sekolah, Semarang: Unissula Press.

Akbar, Sa'dun. (2015). Instrumen perangkat pembelajaran. Bandung: Remaja Rosdakarya.

Amornchewin, Ratchadaporn. (2018). "The Development of SQL Language Skil in Data Definition and Data Manipulation Languages Using Exercises with Quizizz for Students' Learning Engagement". Indonesian Journal of Informatics Education. Vol.2, Issue 2, pp 85-90

Boulden, Cadieux Danielle; Hurt, June W; and Richard, Mary Kathleen. (2017). "Implementing Digital Tools to Support Student Questioning Abilities: A Collaborative Action Research Report". Journal Inquiry in Education. Vol. 9, Issue 1, article 2

Ceker, Eser dan Ozdamli, Fezile. (2017). "What "Gamification" is and What It's Not". European Journal of Contemporary Education. Vol 6(2), pp 221-228

Chaiyo, Yanawut \& Nokham, Ranchana. (2017). The effect of Kahoot, Quizizz and Google Forms on the student's perception in the classrooms response system. 178-182. 10.1109/ICDAMT.2017.7904957.

Cole, M. S., Feild, H. S., \& Harris, S. G. (2004). Student Learning Motivation and Psychological Hardiness: Interactive Effects on Students' Reactions to a Management Class. Academy of Management Learning \& Education, 3(1), 64-85. doi:10.5465/amle.2004.12436819

Harahap, Nurmahni. (2013). Penerapan Model Pembelajaran Kooperatif Tipe STAD terhadap Hasil Belajar Kognitif, Motivasi, dan Aktivitas Belajar Siswa Pada Konsep Ekosistem Di Mtsn Model Banda Aceh. Visipena. Diperoleh dari https://visipena.stkipgetsempena.ac.id/?journal= home\&page $=$ article\&op=view $\&$ path $\% 5 \mathrm{~B} \% 5 \mathrm{D}=59 \&$ path $\% 5 \mathrm{~B} \% 5 \mathrm{D}=60$

Huda, Miftahul. (2013). Cooperative Learning Metode, Teknik, Struktur dan Model Penerapan. Yogyakarta: Pustaka Pelajar

Masran, M. N., Azizi, N. S. A. (2018). Effects of Cooperative Learning (STAD) on Student Achievement in Jawi Among Year Five Pupils. American Scientific Publishers. Volume 24/7. Doi.10.1166/asl.2018.11729

Riduwan. (2013). Metode dan Teknik Menyusun Tesis. Bandung: Alfabeta

Samet, Bal. (2018). "Using Quizizz.com to Enhance Pre-Intermediate Students'Vocabulary Knowledge". International Journal of Language Academy.Volume 6/3 September 2018 p.295/303

Sardiman, A.M., (2012). Interaksi dan Motivasi Proses Belajar Mengajar. Jakarta: PT. Raja Grafindo Persada.

Slavin. R. E. (2015). Cooperative Learning in Schools. International Encyclopedia of the Social E Behavioral Sciences, 4(1). Doi.10.1016/B978-0-08-097086-8.92028-2

Tiantong, M., \& Teemuangsai, S. (2013). Student Team Achievement Divisions (STAD) technique through the moodle to enhance learning achievement. International Education Studies, 6(4). doi:10.5539/ies.v6n4p85

Uno, Hamzah B. (2007). Teori Motivasi dan Pengkurannya : Analisis di Bidang Pendidikan. Jakarta: Bumi Aksara

Utami, P., Basri, W., \& Aisiah, A. (2019). Pengaruh Model STAD Terhadap Hasil Belajar Siswa Pada Mata Pelajaran Sejarah Indonesia. Pakar Pendidikan, 17(1), 13-25.

Widja. I.G. (1988). Pengantar Ilmu Sejarah dalam Perspektif Pendidikan. Semarang: Satya Wacana.

Widja. I G. (1989). Dasar-dasar Pengembangan Strategi Serta Metode Pengajaran Sejarah. Jakarta: P2LPTK.

Wiyono. 2011. Pengertian dan Karakter IPS. Historia Vitae Magistra.Volume 25, no. 2. Universitas Sanata Dharma: Yogyakarta.

Wyk, M. M. V. (2012). The Effects of the STAD-Cooperative Learning Method on Student Achievement, Attitude and Motivation in Economics Education. Journal of Social Sciences. Volume 33. Doi.10.1080/09718923.2012. 11893104

Zainuddin Z., Shujahat M., Haruna H. \& Chu S.K.W. (2019). The role of gamified e-quizzes on student learning and engagement: An interactive gamification solution for a formative assessment system, Computers \& Education), doi: https://doi.org/10.1016/j.compedu.2019.103729.

Zhao, Fang. (2019). Using Quizizz to Integrate Fun Multiplayer Activity in the Accounting Classroom. International Journal of Higher Education Vol. 8, No. 1; 2019..doi.org/10.5430/ijhe.v8n1p37. 